\title{
Dysmorfia płciowa profilu twarzy w analizie cefalometrycznej
}

\author{
Sexual dimorphism of facial profiles in cephalometric analysis
}

\author{
${ }^{1}$ Poradnia Ortodontyczna dla Dzieci, Instytut Matki i Dziecka w Warszawie \\ ${ }^{2}$ Katedra i Klinika Ortopedii Szczękowej i Ortodoncji, Uniwersytet Medyczny im. Karola Marcinkowskiego w Poznaniu \\ ${ }^{3}$ Prywatny Gabinet Ortodontyczny w Ostrowie Wielkopolskim
}

DOI: http://dx.doi.org/10.20883/df.2016.3

\begin{abstract}
Streszczenie
Wstęp. Grupę cech morfologicznych, które odróżniają płeć męską od płci żeńskiej, określa się mianem dysmorfii płciowej.

Cel. Celem pracy była analiza cefalometryczna tkanek miękkich twarzy w grupie dziewcząt i chłopców bez wad wrodzonych części twarzowej czaszki z uwzględnieniem szerokości mezjalno-dystalnej zębów w celu wykazania różnic istniejących pomiędzy płciami we wczesnym okresie dojrzałości.

Materiał i metody. Do analizy wybrano 44 pacjentów, w tym 22 osoby płci żeńskiej (12-15 lat) oraz 22 osoby płci męskiej (14-17 lat) z I klasą szkieletową bez innych wad, które mogłyby mieć wpływ na profil twarzy. Przy pomocy programu komputerowego Ortho Studio 1.1.0.5735 oceniono modele diagnostyczne oraz telerentgenogramy boczne głowy. Przeprowadzono analizy statystyczne uzyskanych pomiarów i na ich podstawie oceniono profil twarzy żeńskiej i męskiej.

Wyniki. Przeprowadzone badania wykazały zróżnicowanie w wartościach analizowanych parametrów: przednio-tylnych wartości zębów między płcią żeńską a męską. Wartości przednio-tylne uzębienia młodych osób okazały się nieco większe niż tzw. wartości referencyjne. Ponadto stwierdzono zróżnicowanie wartości pozostałych parametrów dla dziewcząt i chłopców. Analiza korelacji między przednio-tylną szerokością zębów a cefalometrycznymi parametrami profilu twarzy wykazała dalsze zróżnicowanie twarzy dziewcząt i chłopców, co zostało potwierdzone testami statystycznymi. Zaprezentowane wyniki badań własnych, jak i wyniki badań cytowanych autorów, wskazują, że analizując twarz, planując leczenie ortodontyczne powinno się uwzględniać płeć.
\end{abstract}

Słowa kluczowe: cefalometria, dysmorfizm płciowy, wskaźnik Boltona, analiza tkanek miękkich.

\begin{abstract}
Introduction. The group of morphological features that distinguish a male from a female is called sexual dimorphism. Aim. The aim of this study was to perform cephalometric analysis of the facial soft tissues between a group of boys and girls without congenital craniofacial defects (including the mesial-distal width of the teeth) in order to demonstrate the anatomical differences between genders in the early stages of puberty.

Material and methods. We selected 44 patients for analysis - 22 females (12-15 years) and 22 males (14-17 years) being skeletal class 1 without any disorders that could affect the facial profile. With the help of the Ortho Studio 1.1.0.5735 computer program, models and diagnostic lateral cephalograms were measured. The obtained measurements were analysed and male/female facial profiles were rated on the basis of them.

Results. The study showed differences between the values of the analysed parameters: the anterior-posterior teeth value between males and females. The dentition of young people turned out to be slightly wider than the so-called reference values. Differences between the values of other parameters for girls and boys were found. The correlation analysis between the anterior-posterior width of the teeth and cephalometric facial profile parameters showed a further differentiation between the faces of girls and boys, which was confirmed by statistical tests. The presented results of this research as well as the research by other authors show that in terms of analysing the face, gender should be taken into account when planning orthodontic treatment.
\end{abstract}

Keywords: cephalometric, sexual dimorphism, Bolton Index, soft tissue analysis.

\section{Wstęp}

Dysmorfizm płciowy reprezentuje grupę cech morfologicznych, które odróżniają płeć męską od płci żeńskiej [1]. Różnice w wartościach metrycznych określonych struktur w obrębie szkieletu czaszki i tkanek miękkich twarzy mogą również być tą wykładnią. Wykorzystywane są w tym celu różne analizy telerentgenogramów bocznych głowy [2]. Analiza cefalometryczna pozwala na obiektywną ocenę położenia określonych struktur anatomicznych w obrębie części twarzowej czaszki, wykazuje zmiany w szkielecie czaszki na skutek rozwoju i wzrostu bądź postępowania terapeutycznego [3]. 
Badania cefalometryczne przeprowadzone na grupie pacjentów rasy kaukaskiej dowodzą istnienia różnicy w relacjach szkieletowo-zębowych pomiędzy płciami. Różnice w wartościach niektórych parametrów pomiędzy grupami dziewcząt i chłopców ujawniały się znacząco po 14 roku życia [4]. Uwarunkowane jest to najprawdopodobniej zmianami zachodzącymi w czasie dojrzewania. Okres wzrastania jest zróżnicowany pomiędzy dziewczętami i chłopcami. U dziewczynek skok pokwitaniowy rozpoczyna się około dwu lat wcześniej i zwykle trwa od 8,5 do 13,5 roku życia, zaś u chłopców między 10 a 15 rokiem życia [5]. W badaniach pacjentów z klasą III szkieletową wykazano, iż ta wada zgryzu w znacznym stopniu wiąże się z dysmorfią płciową $w$ obrębie części twarzowej czaszki, zwłaszcza po 13 roku życia [6], aczkolwiek obserwacje innych autorów wykazały różnice w szkielecie części twarzowej czaszki pomiędzy grupami dziewcząt i chłopców już w 10 roku życia [7].

Celem pracy była analiza cefalometryczna określonych parametrów w obrębie tkanek miękkich twarzy w grupie dziewcząt i chłopców bez wad wrodzonych części twarzowej czaszki z uwzględnieniem szerokości mezjalno-dystalnej zębów w celu wykazania różnic istniejących pomiędzy płciami we wczesnym okresie dojrzałości.

\section{Materiał i metody}

Materiał badany stanowiła wyjściowa dokumentacja konsultowanych ortodontycznie osób młodych: historie chorób, modele diagnostyczne, pantomogramy oraz telerentgenogramy boczne głowy. Z licznej bazy wybrano wyłącznie dokumentację pacjentów bez wad morfologicznych i wad wrodzonych części twarzowej czaszki, obojga płci w wieku 12-17 lat (płci żeńskiej w przedziale 12-15 lat oraz płci męskiej w przedziale 14-17 lat). Ten etap kwalifikacji różnicował grupy wiekowo, gdyż uwzględniał zróżnicowaną dojrzałość szkieletową pomiędzy grupami. Kolejnym kryterium doboru w oparciu o analizę cefalometryczną - był brak wad, które mogłyby mieć wpływ na profil twarzy. Przeanalizowano wielkość pomiaru Wits i kąta ML-SN, co pozwoliło na wybranie osób z I klasą szkieletową (zakres od -2 do $+2 \mathrm{~mm}$ ) i kątem ML-SN (zakres $33^{\circ} \pm 6^{\circ}$ ), wykluczając zaburzenia $w$ relacjach pionowych. Następnie na podstawie pantomogramów zakwalifikowano do badań osoby bez braków w uzębieniu stałym (nie uwzględniano trzecich zębów trzonowych). Do ostatecznej analizy wybrano dokumentację 44 osób w równolicznych zbiorach, po 22 przypadki w każdej grupie, uwzględniając płeć. $Z$ dokumentacji wynikało, że w grupie żeńskiej najmłodsza osoba miała 12 lat a najstarsza 14 lat, mediana 13,15 przy współczynniku zmienności 6,6\%. W grupie męskiej najmłodsza osoba miała 14 lat a najstarsza 17 lat, mediana 14,55 przy współczynniku zmienności 12,1\%.
W badanych grupach dziewcząt i chłopców z I klasą szkieletową stwierdzono wyłącznie niewielkie nieprawidłowości o charakterze zaburzeń bez wpływu na tkanki miękkie twarzy. Rozkład zaburzeń był podobny w grupie męskiej i żeńskiej. Zatem uzyskano do porównań bardzo jednorodny materiał badany.

\section{Metodyka badania}

Do oceny radiogramów i modeli diagnostycznych zastosowano program komputerowy Ortho Studio 1.1.0.5735. Na podstawie telerentgenogramów bocznych głowy oceniono profil twarzy żeńskiej i męskiej. Badanie cefalometryczne według Steinera obejmowało pomiary liniowe, kątowe i proporcje. W analizie profilu tkanek miękkich twarzy uwzględniono położenie bródki, wargi górnej, wargi dolnej i proporcji pionowych środkowego i dolnego odcinka twarzy. Na podstawie skanowanych modeli diagnostycznych obliczono wskaźnik Boltona przednio-tylną szerokość zębów. Program wygenerował wynik liczony według wzoru dla wskaźnika Boltona przedniego AR = suma szerokości mezjalno-dystalnych sześciu przednich zębów żuchwy / suma szerokości mezjalno-dystalnych sześciu przednich zębów szczęki x $100=77,2 \% \pm$ 0,22 oraz dla wskaźnika Boltona całkowitego OR = suma szerokości mezjalno-dystalnej dwunastu zębów żuchwy/suma szerokości mezjalno-dystalnej dwunastu zębów szczęki x $100=91,3 \% \pm 0,26$. W programie wyniki pomiarów zliczane były automatycznie, zestawiane w tabeli, a wynik ostateczny wskaźnika przedniego i całkowitego podany był $z$ odchyleniem od wartości referencyjnych sugerowanych przez Boltona.

Charakterystykę badanych cech cefalometrycznego profilu tkanek miękkich twarzy oraz wielkości wskaźników: przedniego i całkowitego, oparto na podstawowych statystykach opisowych. Do analizy oddziaływania pomiędzy każdą parą badanych cech opisujących współzależność wskaźników Boltona z cefalometryczną oceną profilu tkanek miękkich twarzy użyto współczynnika korelacji rang Spearmana przyjmującego wartości z przedziału od -1 do 1, badając jego statystyczną istotność, a następnie siłę związku korelacyjnego między cechami, o ile współczynnik korelacji był istotny. Przyjęto, że istotny związek korelacyjny jest słaby, gdy wartość współczynnika korelacji rang Spearmana co do bezwzględnej wartości nie przekracza 0,5, średni - jeśli mieści się w przedziale od 0,5 do 0,75 , silny - w przedziale od 0,75 do 0,95 oraz bardzo silny - co najmniej 0,95 . Analiza wyników została przeprowadzona z wykorzystaniem programu komputerowego STATISTICA PL.

\section{Wyniki}

Przeprowadzone badania wykazały zróżnicowanie w wartościach analizowanych parametrów: przednio-tylnych wartości zębów pomiędzy płcią, 
jak i w odniesieniu do wartości podanych przez Boltona. Uzębienie młodych osób okazało się nieco szersze niż tzw. wartości referencyjne. Ponadto stwierdzono zróżnicowanie wartości pozostałych parametrów dla dziewcząt i chłopców (Tabela 1).

Analiza korelacji między przednio-tylna szerokością zębów a cefalometrycznymi parametrami profilu twarzy wykazała dalsze zróżnicowanie pomiędzy twarzą płci żeńskiej a płci męskiej w młodym wieku, co zostało potwierdzone testami statystycznymi (Tabela 2).

\section{Dyskusja}

W wynikach badań własnych wartości wybranych parametrów profilu twarzy oraz wartości wskaźników przedniego i całkowitego Boltona różniły się pomiędzy płciami, potwierdzając tym samym obecność dysmorfii płciowej. Stwierdzono istotność statystyczną w związkach korelacyjnych między szerokością mezjalno-dystalną zębów a wybranymi parametrami profilu twarzy u młodych osób z uwzględnieniem płci. Wysokość środkowego odcinka twarzy u dziewcząt miała śred- ni stopień korelacji w stosunku do całkowitego wskaźnika Boltona, przy czym w grupie chłopców tej korelacji nie odnotowano. Natomiast obecność korelacji w wysokości dolnego odcinka twarzy, długości wargi górnej oraz długości wargi dolnej do wskaźników Boltona stwierdzono tylko w grupie chłopców.

W piśmiennictwie nie znaleziono prac oryginalnych różnicujących profil żeński i męski w powiązaniu z szerokością uzębienia, stąd trudności w podjęciu dyskusji nad wynikami badań zaprezentowanymi przez nas. Istnieją jednak prace przeprowadzone w oparciu o analize cefalometryczną, wykorzystujące nieco inną metodologię badań, które potwierdzają zróżnicowanie twarzy pomiędzy płciami.

W badaniu Turkkahraman i Gokalp na telerentgenogramy boczne głowy nakładano fotografie profilowe twarzy i taką kompozycję autorzy poddali ocenie 400 sędziów. Analiza profilu oceniana była między innymi w aspekcie płci i wieku oraz indywidualnych cech. Autorzy wywnioskowali, że profil ortognatyczny był najbardziej preferowany u obu

Tabela 1. Uśrednione wartości wybranych parametrów profilu twarzy i wartości wskaźników przedniego i całkowitego Boltona u młodych osób (z uwzględnieniem płci)

Table 1. Mean values of selected facial profile parameters and measurement values of the anterior and overall Bolton ratio

\begin{tabular}{|c|c|c|c|c|c|c|c|c|c|c|c|}
\hline & $\begin{array}{c}\text { Kąt } \\
\text { tkanek } \\
\text { miękkich } \\
\text { twarzy }\end{array}$ & $\begin{array}{l}\text { Wydat- } \\
\text { ność } \\
\text { wargi } \\
\text { górnej - } \\
\text { kąt H }\end{array}$ & $\begin{array}{c}\text { Kąt } \\
\text { nosowo- } \\
\text {-wargowy }\end{array}$ & $\begin{array}{l}\text { Wysokość } \\
\text { środko- } \\
\text { wego } \\
\text { odcinka } \\
\text { twarzy }\end{array}$ & $\begin{array}{c}\text { Wysokość } \\
\text { dolnego } \\
\text { odcinka } \\
\text { twarzy }\end{array}$ & $\begin{array}{l}\text { Długość } \\
\text { wargi } \\
\text { górnej }\end{array}$ & $\begin{array}{c}\text { Długość } \\
\text { wargi } \\
\text { dolnej }\end{array}$ & $\begin{array}{c}\text { Stosunek } \\
\text { wysokości } \\
\text { twarzy }\end{array}$ & $\begin{array}{l}\text { Stosunek } \\
\text { wysokości } \\
\text { warg }\end{array}$ & $\begin{array}{c}\text { AR- } \\
\text { Boltona } \\
\text { wartość } \\
\text { referen- } \\
\text { cyjna } \\
-77,2\end{array}$ & $\begin{array}{c}\text { OR- } \\
\text { Boltona } \\
\text { wartość } \\
\text { referen- } \\
\text { cyjna } \\
-91,3\end{array}$ \\
\hline \multicolumn{12}{|c|}{ Dziewczęta } \\
\hline Minimum & 85,15 & 5,41 & 105,20 & 58,22 & 60,41 & 19,41 & 50,28 & 0,88 & 0,36 & 72,03 & 86,45 \\
\hline Kwartyl dolny & 89,08 & 10,83 & 110,80 & 65,73 & 64,43 & 21,20 & 51,78 & 0,92 & 0,38 & 75,98 & 90,39 \\
\hline $\begin{array}{l}\text { Mediana } \\
\text { brzegowa }\end{array}$ & 90,48 & 13,37 & 118,63 & 67,25 & 68,39 & 23,38 & 54,95 & 0,97 & 0,41 & 78,18 & 92,73 \\
\hline $\begin{array}{l}\text { Średnia } \\
\text { arytmetyczna }\end{array}$ & 90,81 & 13,21 & 116,78 & 67,09 & 68,65 & 23,00 & 54,89 & 0,98 & 0,42 & 77,88 & 92,37 \\
\hline Kwartyl górny & 92,56 & 15,89 & 121,34 & 70,25 & 72,06 & 24,69 & 56,53 & 1,03 & 0,45 & 80,46 & 94,75 \\
\hline Maksimum & 96,71 & 20,32 & 132,05 & 71,28 & 79,57 & 27,61 & 66,38 & 1,12 & 0,50 & 82,95 & 96,34 \\
\hline $\begin{array}{l}\text { Odchylenie } \\
\text { standardowe }\end{array}$ & 2,9 & 3,7 & 7,2 & 3,5 & 4,9 & 2,2 & 3,9 & 0,1 & 0,1 & 3,1 & 2,9 \\
\hline $\begin{array}{l}\text { Współczynnik } \\
\text { zmienności (w \%) }\end{array}$ & 3,19 & 28,08 & 6,13 & 5,20 & 7,15 & 9,63 & 7,14 & 7,34 & 9,72 & 4,04 & 3,17 \\
\hline \multicolumn{12}{|c|}{ Chłopcy } \\
\hline Minimum & 86,53 & 9,96 & 106,56 & 63,09 & 66,36 & 19,70 & 50,07 & 0,80 & 0,33 & 73,32 & 88,68 \\
\hline Kwartyl dolny & 90,03 & 13,04 & 107,53 & 67,80 & 69,96 & 24,17 & 54,91 & 0,90 & 0,41 & 76,30 & 90,71 \\
\hline $\begin{array}{l}\text { Mediana } \\
\text { brzegowa }\end{array}$ & 91,01 & 14,41 & 113,74 & 69,85 & 72,53 & 25,50 & 57,46 & 0,95 & 0,45 & 77,99 & 92,72 \\
\hline $\begin{array}{l}\text { Średnia } \\
\text { arytmetyczna }\end{array}$ & 91,46 & 14,57 & 108,77 & 69,78 & 73,42 & 25,40 & 57,61 & 0,95 & 0,44 & 78,42 & 92,69 \\
\hline Kwartyl górny & 92,48 & 16,10 & 119,18 & 72,62 & 76,48 & 26,71 & 60,06 & 0,99 & 0,47 & 80,30 & 94,17 \\
\hline Maksimum & 98,76 & 18,59 & 126,18 & 76,03 & 85,56 & 31,18 & 67,33 & 1,11 & 0,54 & 85,58 & 96,67 \\
\hline $\begin{array}{l}\text { Odchylenie } \\
\text { standardowe }\end{array}$ & 3,0 & 2,4 & 22,0 & 4,0 & 4,8 & 2,4 & 4,2 & 0,1 & 0,1 & 2,9 & 2,3 \\
\hline $\begin{array}{l}\text { Współczynnik } \\
\text { zmienności (w \%) }\end{array}$ & 3,29 & 16,53 & 20,22 & 5,67 & 6,51 & 9,31 & 7,21 & 7,47 & 10,86 & 3,73 & 2,43 \\
\hline
\end{tabular}


Tabela 2. Związki korelacyjne między szerokością mezjalno-dystalną zębów a wybranymi parametrami profilu twarzy u młodych osób z uwzględnieniem płci

Table 2. Correlations between the mesio-distal width of the teeth and selected parameters of the facial profile in young people according to gender

\begin{tabular}{|c|c|c|c|c|c|c|c|c|c|}
\hline & $\begin{array}{c}\text { Kąt tkanek } \\
\text { miękkich } \\
\text { twarzy }\end{array}$ & $\begin{array}{c}\text { Wydatność } \\
\text { wargi górnej } \\
\text { - kąt H }\end{array}$ & $\begin{array}{l}\text { Kąt nosowo- } \\
\text {-wargowy }\end{array}$ & $\begin{array}{l}\text { Wysokość } \\
\text { środkowego } \\
\text { odcinka } \\
\text { twarzy }\end{array}$ & $\begin{array}{c}\text { Wysokość } \\
\text { dolnego } \\
\text { odcinka } \\
\text { twarzy }\end{array}$ & $\begin{array}{c}\text { Długość } \\
\text { wargi górnej }\end{array}$ & $\begin{array}{c}\text { Długość } \\
\text { wargi dolnej }\end{array}$ & $\begin{array}{c}\text { Stosunek } \\
\text { wysokości } \\
\text { twarzy }\end{array}$ & $\begin{array}{c}\text { Stosunek } \\
\text { długości } \\
\text { warg }\end{array}$ \\
\hline \multicolumn{10}{|c|}{ Dziewczęta } \\
\hline \multirow{2}{*}{$\begin{array}{l}\text { Wskaźnik } \\
\text { przedni } \\
\text { Boltona AR }\end{array}$} & $-0,169$ & $-0,097$ & $-0,152$ & $-0,335$ & 0,140 & 0,050 & $-0,048$ & $-0,321$ & 0,161 \\
\hline & $\begin{array}{c}\text { Brak } \\
\text { związku } \\
\text { korelacyj- } \\
\text { nego }\end{array}$ & $\begin{array}{c}\text { Brak } \\
\text { związku } \\
\text { korelacyj- } \\
\text { nego }\end{array}$ & $\begin{array}{c}\text { Brak } \\
\text { związku } \\
\text { korelacyj- } \\
\text { nego }\end{array}$ & $\begin{array}{c}\text { Brak } \\
\text { związku ko- } \\
\text { relacyjnego }\end{array}$ & $\begin{array}{c}\text { Brak } \\
\text { związku } \\
\text { korelacyj- } \\
\text { nego }\end{array}$ & $\begin{array}{c}\text { Brak } \\
\text { związku } \\
\text { korelacyj- } \\
\text { nego }\end{array}$ & $\begin{array}{c}\text { Brak } \\
\text { związku } \\
\text { korelacyj- } \\
\text { nego }\end{array}$ & $\begin{array}{c}\text { Brak } \\
\text { związku } \\
\text { korelacyj- } \\
\text { nego }\end{array}$ & $\begin{array}{c}\text { Brak } \\
\text { związku } \\
\text { korelacyj- } \\
\text { nego }\end{array}$ \\
\hline \multirow{2}{*}{$\begin{array}{l}\text { Wskaźnik } \\
\text { całkowity } \\
\text { Boltona OR }\end{array}$} & $-0,197$ & $-0,150$ & $-0,025$ & $-0,565$ & $-0,143$ & $-0,176$ & $-0,246$ & $-0,174$ & 0,082 \\
\hline & $\begin{array}{c}\text { Brak } \\
\text { związku } \\
\text { korelacyj- } \\
\text { nego }\end{array}$ & $\begin{array}{c}\text { Brak } \\
\text { związku } \\
\text { korelacyj- } \\
\text { nego }\end{array}$ & $\begin{array}{c}\text { Brak } \\
\text { związku } \\
\text { korelacyj- } \\
\text { nego }\end{array}$ & $\begin{array}{c}\text { Średni } \\
\text { związek } \\
\text { korelacyjny }\end{array}$ & $\begin{array}{c}\text { Brak } \\
\text { związku } \\
\text { korelacyj- } \\
\text { nego }\end{array}$ & $\begin{array}{c}\text { Brak } \\
\text { związku } \\
\text { korelacyj- } \\
\text { nego }\end{array}$ & $\begin{array}{c}\text { Brak } \\
\text { związku } \\
\text { korelacyj- } \\
\text { nego }\end{array}$ & $\begin{array}{c}\text { Brak } \\
\text { związku } \\
\text { korelacyj- } \\
\text { nego }\end{array}$ & $\begin{array}{c}\text { Brak } \\
\text { związku } \\
\text { korelacyj- } \\
\text { nego }\end{array}$ \\
\hline \multicolumn{10}{|c|}{ Chłopcy } \\
\hline \multirow{2}{*}{$\begin{array}{l}\text { Wskaźnik } \\
\text { przedni } \\
\text { Boltona AR }\end{array}$} & $-0,208$ & 0,145 & $-0,064$ & 0,104 & 0,497 & 0,405 & 0,478 & $-0,365$ & $-0,065$ \\
\hline & $\begin{array}{c}\text { Brak } \\
\text { związku } \\
\text { korelacyj- } \\
\text { nego }\end{array}$ & $\begin{array}{c}\text { Brak } \\
\text { związku } \\
\text { korelacyj- } \\
\text { nego }\end{array}$ & $\begin{array}{c}\text { Brak } \\
\text { związku } \\
\text { korelacyj- } \\
\text { nego }\end{array}$ & $\begin{array}{c}\text { Brak } \\
\text { związku } \\
\text { korelacyj- } \\
\text { nego }\end{array}$ & $\begin{array}{c}\text { Słaby } \\
\text { związek } \\
\text { korelacyjny }\end{array}$ & $\begin{array}{c}\text { Brak } \\
\text { związku } \\
\text { korelacyj- } \\
\text { nego }\end{array}$ & $\begin{array}{c}\text { Słaby } \\
\text { związek } \\
\text { korelacyjny }\end{array}$ & $\begin{array}{c}\text { Brak } \\
\text { związku } \\
\text { korelacyj- } \\
\text { nego }\end{array}$ & $\begin{array}{c}\text { Brak } \\
\text { związku } \\
\text { korelacyj- } \\
\text { nego }\end{array}$ \\
\hline \multirow{2}{*}{$\begin{array}{l}\text { Wskaźnik } \\
\text { całkowity } \\
\text { Boltona OR }\end{array}$} & $-0,310$ & 0,058 & 0,118 & $-0,027$ & 0,429 & 0,495 & 0,390 & $-0,397$ & 0,120 \\
\hline & $\begin{array}{c}\text { Brak } \\
\text { związku } \\
\text { korelacyj- } \\
\text { nego }\end{array}$ & $\begin{array}{c}\text { Brak } \\
\text { związku } \\
\text { korelacyj- } \\
\text { nego }\end{array}$ & $\begin{array}{c}\text { Brak } \\
\text { związku } \\
\text { korelacyj- } \\
\text { nego }\end{array}$ & $\begin{array}{c}\text { Brak } \\
\text { związku } \\
\text { korelacyj- } \\
\text { nego }\end{array}$ & $\begin{array}{c}\text { Słaby } \\
\text { związek } \\
\text { korelacyjny }\end{array}$ & $\begin{array}{c}\text { Słaby } \\
\text { związek } \\
\text { korelacyjny }\end{array}$ & $\begin{array}{c}\text { Brak } \\
\text { związku } \\
\text { korelacyj- } \\
\text { nego }\end{array}$ & $\begin{array}{c}\text { Brak } \\
\text { związku } \\
\text { korelacyj- } \\
\text { nego }\end{array}$ & $\begin{array}{c}\text { Brak } \\
\text { związku } \\
\text { korelacyj- } \\
\text { nego }\end{array}$ \\
\hline
\end{tabular}

płci, a najmniej profil wypukły. U kobiet preferowane były pełne, wysunięte usta, u mężczyzn cofnięte usta $z$ widocznym nosem. Preferencja profilu ortognatycznego i profilu wypukłego u kobiet była zależna od wieku, u mężczyzn tej zależności nie zaobserwowano [8]. Davis uwzględnił w analizie podział profilu twarzy na prosty, wklęsły i wypukły stwierdzając, że analiza cefalometryczna głowy jest pomocna w ustaleniu kostnych relacji twarzy w stosunku do zębów i kości wyrostka zębodołowego [9]. Naini i Gill stwierdzili, że wypukłość twarzy wskazuje na II klasę szkieletową, czyli wadę dotylną, zaś wklęsły profil twarzy wskazuje na III klasę szkieletową, czyli wadę doprzednią. Zarys profilu nosa, spłaszczona warga górna, rozwarty kąt nosowo-wargowy może świadczyć o niedoborach kostnych - hipoplazji w obrębie szkieletu środkowego odcinka twarzy. Autorzy podali kilka użytecznych analiz profilu tkanek miękkich twarzy zaznaczając, że analizy stanowią jedynie pewne wskazówki, które powinny być brane pod uwagę w kompleksowej diagnostyce ortodontycznej [10].
Szychta i wsp. podali, że zakres prawidłowych wartości antropometrycznych różni się u mężczyzn i u kobiet także wśród rasy kaukaskiej, mongolskiej i negroidalnej. Wysokość nosa, indeks nosa, długość obu nozdrzy są u kobiet rasy kaukaskiej mniejsze niż u mężczyzn. Indeks nosa u kobiet wynosił 57,72\%, a 58,25\% u mężczyzn [11]. Dobrowolska-Zarzycka i wsp. badali współzależność kąta nosowo-wargowego od położenia żuchwy i klasy szkieletowej oraz płci. Autorzy stwierdzili, że wartość kąta nosowo-wargowego jest wypadkową klasy szkieletowej położenia punktu B oraz nachylenia osi długiej zębów siecznych górnych. Wraz ze wzrostem kąta SNB oraz zmniejszeniem wartości kąta ANB wartość kąta nosowo-wargowego ulega zmniejszeniu. W zależności od płci średnie wartości kąta nosowo-wargowego wynosiły dla kobiet $110,5^{\circ}$, a dla mężczyzn $113,8^{\circ}$ [12]. Reyneke i Ferretti stwierdzili, że badając profil twarzy należy brać pod uwage jej podział na trzy odcinki, które są sobie równe z uwzględnieniem trójpodziału odcinka dolnego i kąty: nosowo-wargowy 
- 85-105, kąt wargowo-bródkowy - około $120^{\circ}$, kąt wargowo-bródkowy-podbródkowy - 110-120 i kąt profilu twarzy E - około $13^{\circ}$ dla kobiet i - około11 ${ }^{\circ}$ dla mężczyzn. Ważna dla tych autorów była również ocena estetyki warg i bródki. Odległość wargi górnej i dolnej od linii estetycznej wynosiła odpowiednio około $4 \mathrm{~mm}$ i $2 \mathrm{~mm}$ (przy założeniu tych autorów, że obie wargi powinny leżeć na linii estetycznej). Wysokość bródki mierzona od punktów skórnych stomion do menton wynosiła około $40 \mathrm{~mm}$ dla kobiet i około $42 \mathrm{~mm}$ dla mężczyzn [13]. Wyniki analiz uzyskane przez cytowanych autorów, pomimo różnic $w$ wartościach wyników naszych badań wyraźnie ukazują dysmorfizm płciowy profilu twarzy.

Najnowsze obserwacje przeprowadzone z użyciem skanera na grupie 654 osób narodowości sudańskiej (327 osób płci męskiej i 327 płci żeńskiej, w wieku 4-30 lat) wykazały istnienie różnic w pomiarach w obrębie tkanek miękkich pomiędzy płciami w różnych przedziałach wiekowych. Płeć miała istotny wpływ na wartości kątów oceniających wypukłość bródkowo-wargową oraz wypukłość szczęki. Kąt wypukłości nosa oraz kąt międzywargowy u kobiet zwiększał swoje wartości wraz ze wzrostem, podczas gdy kąty nosowo-wargowy oraz bródkowo-wargowy malały. U mężczyzn kąt wypukłości szczęki wzrastał po okresie dojrzewania. Również odległość górnej oraz dolnej wargi od linii estetycznej Rickettsa była istotnie większa u płci męskiej, ale różnica ta malała wraz z wiekiem. Różnice w morfologii twarzy pomiędzy płciami zostały zatem potwierdzone współczesną metodologią badań [14].

\section{Podsumowanie}

Z zaprezentowanych wyników badań własnych jak i badań cytowanych autorów, którzy posłużyli się różną metodyką, wynika, że analizując twarz, planując leczenie ortodontyczne powinno się uwzględniać płeć. Jednakże w większości doniesień naukowych efekty terapii ortodontycznej w poszczególnych grupach wiekowych, pomimo rozróżnienia w materiale badanym płci, są podawane łącznie dla obu płci. Dobrze zaplanowane, ortodontyczne postępowanie lecznicze u dzieci i młodzieży, uwzględniające cechy dysmorficzne może mieć korzystny wpływ na wygląd pacjenta w wieku dorosłym.

\section{Oświadczenia}

Oświadczenie dotyczące konfliktu interesów

Autorzy deklarują brak konfliktu interesów w autorstwie oraz publikacji pracy.

Źródła finansowania

Autorzy deklarują brak źródeł finansowania.

\section{Piśmiennictwo}

[1] Ayoub F, Rizk A, Yehya M, Cassia A, Chartouni S, Atiyeh F, Majzoub ZJ. Sexual dimorphism of mandibular angle in a Lebanese sample Forensic Leg Med. 2009;16(3):121124.

[2] Cudziło D, Krajewska J, Matthews-Kozanecka M, Kopczyński P. Zastosowanie cefalometrii w leczeniu ortodontyczno-chirurgicznym na podstawie przeglądu piśmiennictwa. Asyst HigStomatol. 2015;10(1):11-19.

[3] Cudziło D. Zastosowanie cefalometrii w diagnostyce i terapii. Przegląd piśmiennictwa oraz badania własne. W: Kubisz L, Matthews-Brzozowska T, Hojan-Jezierska D, Jaroszyk F, Lisiecka-Opalko K (red.). Fizykodiagnostyka i rehabilitacja w medycynie i stomatologii. Wydawnictwo Państwowej Wyższej Szkoły Zawodowej im. Stanisława Staszica w Pile. Piła 2015; 29-40.

[4] Ursi WJ, Trotman CA, McNamara JA Jr, Behrents RG. Sexual dimorphism in normal craniofacial growth. Angle Orthod 1993;63(1):47-56.

[5] Szilagyi-Pągowska I. Charakterystyka rozwoju somatycznego w okresie dojrzewania. Postępy Nauk Medycznych. 2006;6:316-320.

[6] Baccetti T, Brian C. Reyes BC, McNamara JA Jr. Gender Differences in Class III Malocclusion. Angle Orthod. 2005;75(4):510-520.

[7] Obloj B, Fudalej P, Dudkiewicz Z. Cephalometric Standards for Polish 10-Year-Olds with Normal Occlusion. Angle Orthod. 2008;78(2):262-269.

[8] Turkkahraman H, Gokalp H. Facial profile preferences among various layers of Turkish population. Angle Orthod. 2004;74:640-647.

[9] Davis NC. Smile design. Dent Clin North Am. 2007;51:229318.

[10] Naini FB, Gill DS. Facial aesthetics: 2 Clinical assessment. Dent Update. 2008;35:159-170.

[11] Szychta P, Rykała J, Kruk-Jeromin J. Individual and ethnic aspects of preoperative planning for posttraumatic rhinoplasty. Eur J Plast Surg. 2011;34:245-249.

[12] Dobrowolska-Zarzycka M, Mitura I, Sidorowicz $Ł$, Dunin-Wilczyńska I. Wartości kąta nosowo-wargowego w zależności od położenia żuchwy oraz klasy szkieletowej. Forum Orthod. 2012;8:7-15.

[13] Reyneke PJ, Ferretti C. Kliniczna ocena estetyki twarzy. Stom Estet. 2012;8:224-239.

[14] Sforza C, Dolci C, Gibelli DM, Codari M, Pucciarelli V, Ferrario VF, Elamin F. Age-related and sex-related changes in the normal soft tissue profile of native Northern Sudanese subjects: a cross-sectional study. $\mathrm{Br} \mathrm{J}$ Oral Maxillofac Surg. 2016;54(2):192-197.

Zaakceptowano do edycji: 2016-04-28 Zaakceptowano do publikacji: 2016-05-06
Adres do korespondencji:

Dorota Cudziło

Poradnia Ortodontyczna dla Dzieci Instytut Matki i Dziecka w Warszawie ul. Kasprzaka 17A, 01-211 Warszawa tel.: 223277128 e-mail: dcudzilo@gmail.com 